Provided for non-commercial research and education use. Not for reproduction, distribution or commercial use.

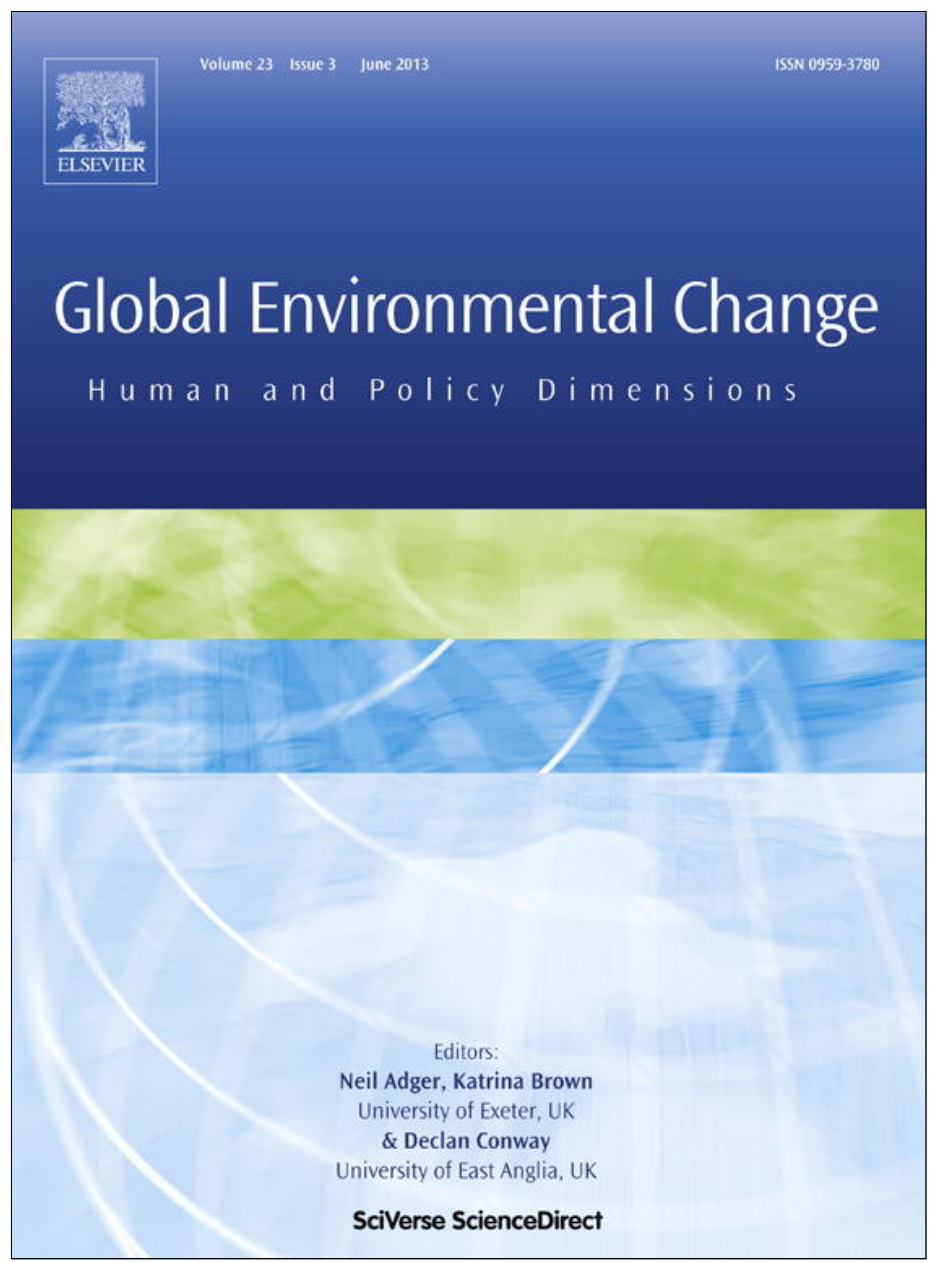

This article appeared in a journal published by Elsevier. The attached copy is furnished to the author for internal non-commercial research and education use, including for instruction at the authors institution and sharing with colleagues.

Other uses, including reproduction and distribution, or selling or licensing copies, or posting to personal, institutional or third party websites are prohibited.

In most cases authors are permitted to post their version of the article (e.g. in Word or Tex form) to their personal website or institutional repository. Authors requiring further information regarding Elsevier's archiving and manuscript policies are encouraged to visit:

http://www.elsevier.com/authorsrights 


\title{
Linking multi-level governance to local common-pool resource theory using fuzzy-set qualitative comparative analysis: Insights from twenty years of biodiversity conservation in Costa Rica
}

\author{
Xavier Basurto* \\ Nicholas School of the Environment, Duke University, USA
}

\section{A R T I C L E I N F O}

\section{Article history:}

Received 29 February 2012

Received in revised form 9 January 2013

Accepted 27 February 2013

\section{Keywords:}

Multi-level governance

Common-pool resources

Biodiversity conservation

Costa Rica

Qualitative comparative analysis

\begin{abstract}
A B S T R A C T
Understanding the relationship between multi-level institutional linkages and conditions influencing the likelihood of successful collective action has practical and theoretical relevance to sustainable local resource governance. This paper studies the relationship between multi-level linkages and local autonomy, a facilitating condition found to increase the likelihood of local successful collective action. A technique known as fuzzy-set qualitative comparative analysis (fsQCA) was applied to a longitudinal comparative data set. In the context of the decentralization of a protected area system in Costa Rica (1986-2006), it traced the emergence and endurance of autonomy among local institutions for biodiversity conservation. The technique illustrates which set of multi-level linkages combined in different ways, and at different points in time, to reach the same outcome (local autonomy). The findings show that a unique set of combinations of multi-level linkages led to the emergence of local autonomy among institutions for biodiversity conservation governance. In contrast, a more diverse set was associated with the endurance of local autonomy over time, suggesting that institutional diversity may play a more prominent role in the maintenance of institutional robustness than in processes of institutional emergence.
\end{abstract}

(c) 2013 Elsevier Ltd. All rights reserved.

\section{Introduction}

Over the last twenty years, scholars have made great strides toward identifying facilitating conditions for the emergence and robustness of successful collective action for local common-pool resource (CPR) governance (Agrawal, 2002). This quest has important implications for our understanding of processes of local and global change, such as the sustainability of vital ecosystem services on which humans depend for their livelihoods (Ostrom, 2005; Persha et al., 2011; Rockström et al., 2009). In moving forward, CPR scholars have pointed toward two areas in need of knowledge development. The first calls for a better understanding of how determinants of emergence and robustness of successful collective action combine with each other in particular contexts (Agrawal, 2002). Ostrom (2009), Rudel (2008), and Young (2002b), among others, have argued that scholars and practitioners need to think less about specific necessary conditions and more about

\footnotetext{
* Current address: Division of Marine Science and Conservation, Nicholas School of the Environment, Duke University, 135 Duke Marine Lab Road, Beaufort, NC 28516, USA. Tel.: +1 252504 7540; fax: +1 2525047648 .

E-mail address: xavier.basurto@duke.edu
}

combinations of necessary and sufficient conditions in a diagnostic fashion. The second area of investigation seeks to understand how multi-level institutional arrangements (i.e., multi-level linkages) affect processes of local institutional change, such as emergence or robustness (Adger et al., 2005; Berkes, 2002; McGinnis and Ostrom, 2008; Young, 2002a).

This paper addresses both of these knowledge gaps by empirically examining how multi-level linkages can facilitate local processes of institutional change using a technique known as fuzzy-set qualitative comparative analysis (fsQCA) (Ragin, 2000). fsQCA allows the investigator to examine many combinations of multi-level linkages as potential conditions of necessity and sufficiency. I illustrate the approach through a longitudinal comparative study of the emergence and endurance of local autonomy for biodiversity conservation among local protected areas in the Central American country of Costa Rica.

Costa Rica is an ideal setting to study multi-level governance in the context of biodiversity conservation because of its demonstrated creativity in developing innovative relationships between local, national, and international institutions for biodiversity conservation purposes for more than twenty years (Boza et al., 1995; Evans, 1999; Gómez and Savage, 1983; Steinberg, 2001). For ten years, the central government promoted the decentralization 
of their protected area management system. In the subsequent ten years, the central government engaged in a recentralization effort. This policy change permitted an assessment over time of how multi-level institutional arrangements affected local institutions' efforts to develop and sustain their local autonomy, a factor often associated with successful resource self-governance.

This paper starts by reviewing insights from CPR theory leading to calls for developing diagnostic assessments, then provides key definitions describing measures used in the analysis and exploring the potential value of fsQCA as a diagnostic analytical tool. The findings provide an account of the types of multi-level interactions in Costa Rica that led to the emergence and endurance of local autonomy across time. Finally, the discussion focuses on how does a configurational analysis contribute to a better understanding of processes of institutional change and, what multi-level interactions influenced biodiversity conservation efforts in Costa Rica.

\subsection{Theoretical background}

1.1.1. Institutional change as processes of emergence and robustness

In the context of CPR theory, institutions are defined as shared understandings among actors about enforced prescriptions concerning what actions (or outcomes) are required, prohibited, or permitted (Commons, 1924; Ostrom, 1980). Institutional emergence involves the adoption or formalization of rule structures that only existed previously as norms or rules-in-use (Ostrom, 2000) or the adaptation or shift from an existing institution to a different or new institution (Ostrom, 1999). In institutionally robust or longenduring settings, resource users usually have institutional arrangements in place enabling them to constantly fiddle and modify rule structures over time to adapt to changing conditions (Anderies et al., 2004; Janssen et al., 2007; Shepsle, 1989; Wilson, 2006). Institutional robustness does not imply that resource users will create optimal rules that remain unchanged over time (Ostrom, 1999).

Because these two broadly encompassing processes of institutional change affect the governance sustainability of common-pool resources, there has been significant interest in identifying conditions that can increase the likelihood of emergence and long-term robustness of institutions (Axelrod, 1984; Baland and Platteau, 1996; Berkes, 1989; McCay and Acheson, 1987; Olson, 1965; Ostrom, 1990; Wade, 1994).

Ostrom $(1990,2000)$ argued that a number of characteristics of the common-pool resource and of its appropriators are associated with an increased likelihood of the emergence of self-organization. Characteristics of the CPR included: feasible improvement, presence of indicators, predictability, and spatial extent, while characteristics of the appropriators included: salience, common understanding, low discount rate, trust and reciprocity, autonomy, and prior organizational experience and local leadership (see Schlager, 2004 for definitions). Alternatively, Ostrom (1990) proposed a different set of conditions (known as Ostrom's eight design principles) that could influence the likelihood that self-governing arrangements would be long-lasting: (1) clearly defined boundaries or exclusion rights, (2) congruence between appropriation and provision rules and local conditions, (3) most individuals affected by the operational rules can participate in modifying rules affecting them, (4) presence of monitoring arrangements where monitors are accountable to the appropriators or are the appropriators, (5) graduated sanctions applied to rule-breakers depending on the seriousness and context of the offense, (6) availability of rapid and low-cost conflictresolution mechanisms, (7) the rights of appropriators to devise their own institutions without being challenged by external governmental authorities, and (8) appropriation, provision, monitoring, enforcement, conflict resolution, and governance activities are organized in multiple layers of nested enterprises.
Other scholars have identified different and somewhat overlapping sets of facilitating conditions (Agrawal, 2002; Pagdee et al., 2006; Cox et al., 2010; Gutierrez et al., 2010). Despite increased interest in the facilitating conditions for institutional emergence and robustness, there is still significant confusion about which facilitating conditions are necessary or sufficient, and in which particular contexts (Agrawal, 2002). Notwithstanding explicit warnings that policy solutions found in particular contexts do not constitute panaceas (Ostrom, 2007), conditions for the emergence and robustness of self-governance are often interpreted as necessary conditions or "blueprints" (i.e., they all need to be present or absent for the outcome to occur). As a way to move away from this "checklist approach," Young et al. (2008a) and Agrawal (2002) proposed focusing instead on how different factors combine with each other in particular contexts. Young (2002b) argued that an institutional diagnostic should be capable of treating each environmental problem as a unique case without losing some generalizability. The idea of a diagnostic approach has been embedded and developed further into a multi-tiered framework for the study of social-ecological systems (Ostrom, 2009). The social-ecological system (SES) framework can highlight the role that multi-level linkages play in generating CPR dilemmas, and the processes of collective action that can address those dilemmas (Heikkila et al., 2011).

Advancing understanding of the role that multi-level linkages play in the management of local CPRs requires better understanding of how such linkages interact with facilitating conditions (e.g., Ostrom's design principles) influencing the likelihood of collective action for institutional emergence and robustness. This is the goal of this paper. Further, I suggest that to adequately do the above, we also need to move away from the interpretation of facilitating conditions as conditions that must be present or absent for the outcome to occur - and toward the study of configurations of conditions. While the call for the study of configurational institutional analysis is not new (Cox, 2011; Heikkila et al., 2011; Rudd et al., 2003; Rudel, 2005; Schlager, 2002), the approach illustrated here relies on fsQCA - a tool designed to study configurational relationships.

\subsubsection{Local autonomy}

This paper examines how multi-level linkages affect local autonomy. Local autonomy is the key outcome of interest and particularly useful for our purposes because it is one of the conditions that is both mentioned as important for the emergence of self-organization as well as for it to be long-lasting (Hayes and Persha, 2010; Ostrom, 2005; Schlager, 2002). As a condition that can increase the likelihood of the emergence of self-organization, autonomy is defined as appropriators' ability "to determine access and harvesting rules without external authorities countermanding them" (Ostrom, 2000, p. 40). As a condition for the robustness of institutions, autonomy is defined as "the rights of appropriators to devise their own institutions [without being] challenged by external governmental authorities" (Ostrom, 1990, p. 90). The close relationship between both definitions makes it feasible to use autonomy as a dependent variable to study how multi-level linkages affect emergence and robustness (i.e., endurance herein) of local institutional autonomy. However, in itself, autonomy is not an indicator or measure of emergence or robustness of institutions.

In arguing how autonomy affects individual incentives to engage in the design and endurance of institutions, Ostrom (1990) pointed at how local appropriators' autonomy affected the costs of transformation to change their own rules; that is, the amount of resources devoted to the process of considering a rule change (Buchanan and Tullock, 1962). "The transformation costs of setting up a strictly private association of appropriators to discuss common problems are considerably less than the transformation 
costs of creating a local public jurisdiction that can impose taxes on all citizens living in its boundaries" (Ostrom, 1990, p. 199). If the latter is embedded in a highly centralized regime, where local-level CPR users have no autonomy to change their operational rules, the up-front transformation costs are likely to be even higher. Appropriators would need to afford the costs of meeting and negotiating with the higher authority in order to convince them to change the rules in such a manner beneficial to them. Transformation costs are likely to be less if local-level actors have some degree of autonomy from the central government. Autonomy allows them to engage in collective-choice processes to determine the rules under which they will govern their CPR. Whether they will actually engage in collective action or not, still depends on the interaction of a larger set of factors that ultimately will determine whether CPR users' expected benefits surpass the overall transaction costs of engaging in rule making.

As in the case of Costa Rica, local authorities gained autonomy when, after an intense negotiation process, the central government transferred duties, responsibilities, and decision-making power to local units of biodiversity conservation governance (Allen, 2001; Basurto, 2013). Although, as it has been documented elsewhere, central bureaucratic structures often face incentives to resist those changes, and often the result is an incomplete and selective transfer of power, authority, and autonomy (Ribot et al., 2006). More often, autonomy is not formally extended to change operational rules but it is determined de facto, by, for instance, the location and the effectiveness of the political regime in which the CPR users are embedded. Local CPR users more remotely located from higher-level authorities (physically and psychologically) can enjoy more autonomy than those in closer proximity. Distance is determined by the "number of officials the political regime employs, the effectiveness of the administrative and political apparatus of the political regime, and the extent of the communication and transportation facilities involved," among other factors (Ostrom, 1990, p. 201).

\subsubsection{Multi-level linkages}

The above theorizing suggests that - whether autonomy is initially formally granted, or de facto obtained - the resultant level of autonomy that each local governance unit can achieve will be influenced by the quality and quantity of linkages they can develop. Unfortunately, the literature on multi-level linkages does not provide any further guidance on this point. While CPR scholars have been pursuing research on multi-level linkages, it has been through three interrelated but typically separate streams: as polycentric institutions (Ostrom, 2000; Ostrom et al., 1961), as comanagement (Berkes et al., 1991; Pinkerton, 1992), and as institutional interplay (Berkes, 2002; Cash et al., 2006; Gunderson and Holling, 2002; McKean, 1996; Young, 1996; Young et al., 2008b). Past studies that have touched on the relationship between multi-level linkages and autonomy have focused on the importance of external, independent non-governmental organizations to help mediate demands on local forest governance systems (Hayes and Persha, 2010), the influence of stakeholders' participation on their autonomy for self-determination (Trench, 2008), and protected area effectiveness (Chowdhury and Koike, 2010). Other scholars have cautioned about the negative consequences that different institutional arrangements at multiple jurisdictional levels can have for effective development aid (Gibson et al., 2005). Yet others have found instances where the support by international donor agencies led to successful protected area buffer zone management (Nagendra et al., 2004). These examples restate the relevant, but mixed, performance that certain kinds of multi-level linkages might have for developing local autonomy. They also resonate with Gibson et al.'s (2000) call for the need to better understand what types of institutional arrangements at

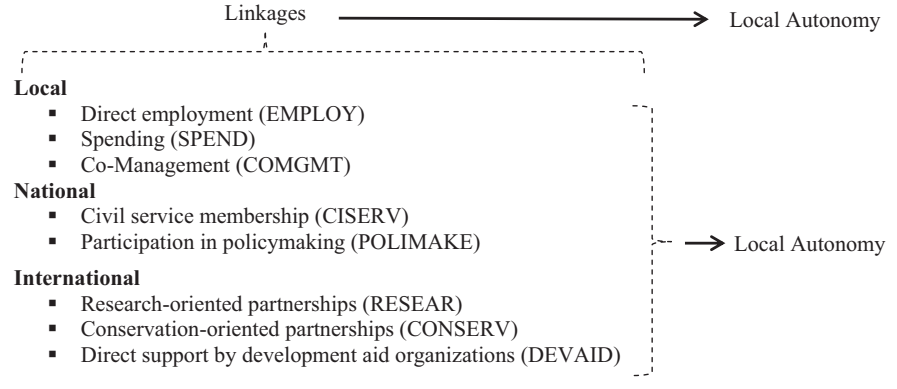

Fig. 1. Conceptual model depicting the relationship between linkages and local autonomy for the decentralization period.

different scales might be more important than others in specific settings.

In the Costa Rican context of this paper, a "linkage" is defined as "a formal rule, strategy, or regularized action that establishes interdependencies among two distinct actors around different tasks" (Heikkila et al., 2011). Based on this definition, the two main tasks on which I focused to identify the linkages for this study consisted of finding interdependencies that could (1) increase local institution's bargaining position to wrestle autonomy from the central government and/or (2) increase local institutions' access to financial or political resources to maintain or increase the autonomy wrestled from the central government. Fig. 1 lists linkages at each political jurisdictional level (i.e., local, national, and international), derived from interviews with key informants during preliminary fieldwork in Costa Rica. Fig. 1 serves as a conceptual model of the relationship between linkages and autonomy for the decentralization period.

At the local level, linkages are between local protected areas and local inhabitants through direct employment, local spending, and developing co-management arrangements to increase political support for the local protected area institutions. These linkages are thought to create a constituency more likely to find incentives to bargain against the central government's attempt to take away local protected area's financial, administrative, or operational autonomy (these measures of local autonomy are defined and operationalized in Section 2.1). Linkages at the national level are between local protected areas and the central government through membership of employees in the Civil Service, or active participation in national-level policymaking on protected area issues. These linkages are thought to create interdependencies by which local protected area institutions can shape their bargaining power with the central government on a diversity of issues, including autonomy. For instance, the more employees of the local protected area unit belong to the Civil Service, the less control the local protected area institution has on its personnel. Finally, international linkages between local protected areas and the international community are thought capable of providing financial and political support to local protected area institutions in the form of funding through development aid organizations, conservation, or researchoriented partnerships. For instance, funding support can increase or maintain autonomy of local protected area institutions at times when the central government may attempt to take away local autonomy by reducing funding allocations. International organizations can also exert political pressure against central governments' efforts to control local protected area institution's agenda for biodiversity conservation by threatening to take away or conditioning other types of ongoing or future support of interest to the central government. Below, I provide more context on the decentralization and recentralization efforts by the Costa Rican central government, and elaborate on measures developed for the multi-level linkages mentioned above and autonomy. 


\subsection{Decentralization and recentralization of biodiversity conservation in Costa Rica}

In 1986, Costa Rica faced mounting national and international pressure to share the benefits of protected areas with the local population and slow down the rapid rates of deforestation outside national parks. In response, the central government engaged in a decentralization project.

The first ten years of the decentralization process involved negotiation of informal arrangements between the central government and individual protected areas, but in 1996, the Costa Rican Congress finally formalized the decentralization effort through the creation of the National Conservation Area System (herein SINAC, its acronym in Spanish). SINAC merged three different agencies (the Forest Service, the National Park Service, and the Wildlife Service), together governing almost $25 \%$ of Costa Rican territory (SINAC-MINAE, 2002), under a decentralized structure organized in eleven regionally based administrative units, labeled as "conservation areas" (Fig. 2).

Under SINAC, each conservation area is formally in charge of governing all of the different protected areas (i.e., forest reserves, national parks, and wildlife refuges) and private property surrounding protected areas within their jurisdiction through a regional director and staff. The focus of this paper is only on the analysis of the conservation areas' role in the management of protected areas.

I will refer to the time from 1986 to 1998 as the "decentralization period" because it opened the possibility for each conservation area to exercise a different degree of local autonomy from the central government through the design of its local activities, governance, and funding structure. By 1998, conservation areas showed varying levels of local autonomy and development of local agendas for biodiversity conservation-related activities. As we will see, the Area de Conservación Guanacaste (ACG, see Fig. 2) enjoyed much more local autonomy than the rest of the conservation areas, most likely because the ACG had played a central role in facilitating the decentralization process (Allen, 2001; Basurto and Jimenez, 2013). In 1998, however, the central government focused on bringing financial equity and a "similar level of development" to all of the different conservation areas, effectively prompting the Office of the Comptroller General to take an unprecedented, strong

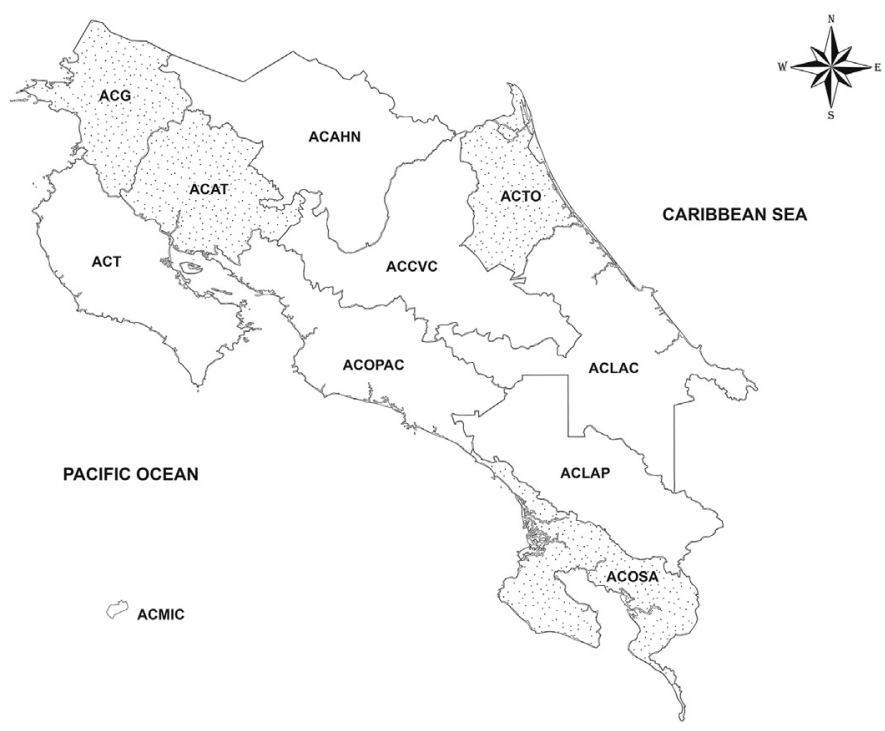

Fig. 2. Acronyms of the eleven regionally based administrative units known as conservation areas of Costa Rica highlighting those included in this study. Modified from SINAC (2013). oversight role. This period is labeled as the "recentralization period" (1998-2006). Despite this new environment of recentralization, conservation areas continued to display varying levels of local autonomy. In the following sections, I explore what types and combinations of cross-level linkages enabled the emergence and endurance of local autonomy, both before and after recentralization efforts.

\section{Research strategy}

\subsection{Operationalization of local autonomy and multi-level linkages in the Costa Rican context}

Understanding how the ACG and other conservation areas were able to gain and sustain their local autonomy from the central government required systematic comparisons of conservation area programs operating within each conservation area. In this context, programs are defined as local units of collective action within each conservation area. They constitute the main unit of analysis due to their variation in levels of local autonomy within and among conservation areas, including the ACG. The following inclusion criteria were used: programs had to show a clear mandate to support biodiversity conservation goals, have more than two members on staff, and could make collective-choice and/or operational decisions regarding management and implementation of biodiversity conservation-related activities and resources. Omitted were programs whose main tasks focused on forestry management and other wildlife and land-use regulations unrelated to protected areas. Examples of programs included in the sample are a "Biological Education Program" that conducts biological or environmental education activities with the local population, and a "Protection Program" that focuses on the prevention of hunting and poaching.

I operationalized Ostrom's (1990) definition of local autonomy as the ability of each local conservation area program to exercise self-governance over decision making and implementation without being immediately or constantly overruled by the central government, usually through the Ministry of the Environment. Measures of local autonomy were identified through five informal interviews with senior personnel who had extensive experience in the decentralization/recentralization process in Costa Rica. Key informants included one senior staff at the Ministry of the Environment, and four upper-level staff members at two conservation areas. The assessment of local autonomy resulted in a composite measure encompassing several financial, administrative, and operational measures described in Table 1.

Multi-level linkages were operationalized as "a formal rule, strategy, or regularized action that establishes interdependencies among two distinct actors around different tasks" (Heikkila et al., 2011) that local programs had developed at each jurisdictional level (i.e., local, national, and international). The criteria used to identify them as a "linkage" is presented in Appendix B. Measures for each linkage at each level, as well as for the outcome of interest (local autonomy), are found in Table 1. To clarify, this study provides an account of the different configurations of linkages within each jurisdictional level (i.e., within local, national, international), not about the different configurations of linkages across jurisdictional levels (i.e., across local, national, international). The latter is entirely feasible but is outside of the scope of this paper.

The selection criteria for the measures presented in Table 1 resulted from participatory observation within each of the study conservation areas and requests to informants to identify key interactions at local, national, and international levels that might have affected the emergence of local program autonomy within conservation areas. This process was conducted during two intense summers (2002-2003) in Costa Rica. These interviews helped to 
Table 1

Measures used to determine local autonomy (the outcome) and each type of multi-linkage (the conditions).

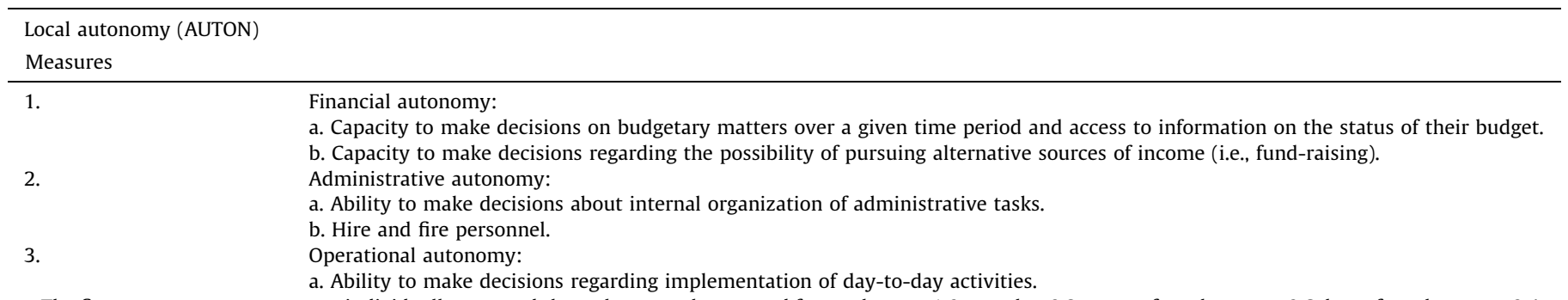

The five separate measures were individually assessed through scores that ranged from: always $=1.0$, mostly $=0.8$, more often than not $=0.6$, less often than not $=0.4$, rarely $=0.2$, never $=0.0$. Sub-measures ( $\mathrm{a}$ and $\mathrm{b}$ ) were averaged for each measure, and the three main measures were averaged to obtain a single "local autonomy" score.

Local level

\begin{tabular}{ll}
\hline Types of local linkages & Measures \\
\hline Local communal involvement through direct employment (EMPLOY) & $\begin{array}{l}\text { Percentage of the program's employees from the protected area's surrounding } \\
\text { communities. } \\
\text { A continuous scale of } 0.0-1.0 \text { was used. } \\
\text { Whether significant amounts of the program's major supplies could be bought locally } \\
\text { (always }=1.0, \text { mostly }=0.8, \text { more often than not }=0.6, \text { less often than not }=0.4,\end{array}$ \\
Co-management with local or regional stakeholders (COMGT) & $\begin{array}{l}\text { Presence }(=1.0) \text { or absence }(=0.0) \text { of formal or informal governance arrangements with } \\
\text { other local individuals (such as private landowners), or institutions (such as boards of } \\
\text { directors, local associations), or governmental agencies (such as the local rural police } \\
\text { office) for decision making. }\end{array}$
\end{tabular}

National level

\begin{tabular}{|c|c|}
\hline Types of national linkages & Measures \\
\hline Degree of influence of National Civil Service policies (CISERV) & $\begin{array}{l}\text { Percentage of employees that belonged to the civil service. The civil service constitutes } \\
\text { an important tool with which the central government controls employees in } \\
\text { governmental agencies throughout the country. A continuous scale of } 0.0 \text { to } 1.0 \text { was } \\
\text { used. }\end{array}$ \\
\hline National participation in policymaking (POLIMAKE) & $\begin{array}{l}\text { Perceived influence }(=1.0) \text { or not }(=0.0) \text { of the program on the design of central } \\
\text { government-level policies that had a direct influence on the program's ability to } \\
\text { conduct their work. }\end{array}$ \\
\hline
\end{tabular}

International level

\begin{tabular}{|c|c|}
\hline Types of international linkages & Measures \\
\hline Research-oriented partnerships (RESEAR) & $\begin{array}{l}\text { Many }(=1.0) \text { or few }(=0.0) \text { formal or informal agreements with research or academic } \\
\text { organizations providing long-term technical advice and/or the generation of scientific } \\
\text { biological or social information. }\end{array}$ \\
\hline Conservation-oriented partnerships (CONSERV) & $\begin{array}{l}\text { Many }(=1.0) \text { or few }(=0.0) \text { formal or informal agreements with international } \\
\text { conservation organizations providing support to program activities. Examples of } \\
\text { support include fund-raising, teaching, volunteering, or donation of goods and services } \\
\text { to the program. An international conservation organization was defined as an } \\
\text { organization that had its main collective-choice decision-making arena outside Costa } \\
\text { Rica. }\end{array}$ \\
\hline Direct support by development aid organizations (DEVAID) & $\begin{array}{l}\text { Availability of direct support from multi-lateral development aid agencies like the } \\
\text { European Union, UNEP, USAID, etc., in the form of grants (always }=1.0 \text {, mostly }=0.8 \text {, } \\
\text { more often than not }=0.6 \text {, less often than not }=0.4 \text {, rarely }=0.2 \text {, never }=0.0 \text { ) and the } \\
\text { presence }(=1.0 \text { ) or absence }(=0.0) \text { of formal international recognition of the protected } \\
\text { area where the program operates (i.e., UN World Heritage Site denomination, etc.). Each } \\
\text { of these two measures was averaged and then aggregated into DEVAID. }\end{array}$ \\
\hline
\end{tabular}

establish that none of the multi-level linkages identified in Table 1 were present in the sampled conservation areas during the "centralization period," during which no program had local autonomy.

The comparative analysis among conservation area programs was conducted within three time periods: the period before local autonomy ("the centralized period," before 1986), the period when the emergence of local autonomy was supported by the central government ("the decentralization period," 1986-1998), and the period when local self-governance was no longer supported ("the recentralization period," 1998-2006).

\subsection{Case selection and data collection}

Of the eleven conservation areas into which Costa Rica's National Conservation Area System is organized (Fig. 2), I analyzed sixteen programs found in four areas: the Guanacaste Conservation Area (ACG) $(n=8)$, the Osa Conservation Area (ACOSA) $(n=3)$, the Tortugero Conservation Area (ACTO) $(n=2)$, and the ArenalTempisque Conservation Area (ACAT) $(n=3)$. The choice of conservation areas was determined by their relevance for biodiversity conservation purposes based on the opinions of experienced policymakers, the feasibility of access to reliable information, and the perceived variation of local autonomy from the central government that their programs had reached (Allen, 2001; Janzen, 2002; Sanchez-Azofeifa et al., 2005). The sixteen programs in the sample represent $46 \%$ of the total number of programs existing in all eleven conservation areas in Costa Rica. Fourteen additional programs had been identified but nine had no direct connection to biodiversity conservation activities and five existed only on paper or had minimal operational activities. The large number of ACG programs included in the study, compared to 
the other conservation areas, constitutes a proportional measure of the number of programs directly relevant to biodiversity conservation goals.

Data collection took place mostly through in-person semistructured and structured interviews with key informants during field visits for a total of sixteen months between 2002 and 2006. Informants included conservation area personnel (i.e., program personnel such as park guards, program coordinators, and directors), members of the central government (previous and current directors of the protected area system and senior-level officials at SINAC, senior advisors to the Minister of the Environment and the Minister of the Environment himself), and directors or knowledgeable individuals who worked for local, national, and internationally based NGOs that formally and informally interacted with conservation area programs. I also relied on archival records: ACG (1991), Arguedas (2002), Arguedas and Rodríguez (2003), Bermudez (1990), Durán and Sánchez (1989), García (1996), García and Ortiz (1991), Matamoros (2002), Mena and Artavia (2004), SINAC-MINAE (2003, 2006), and Ugalde (1989).

Once interviews were summarized or transcribed, the selected measures were coded using continuous, semi-continuous, or dichotomous values as appropriate (see Table 1). In general, interviews started with open-ended questions and were proceeded by narrowing the scope to the specific measure of interest. Followup questions or interviews were often necessary for those measures using a modified Likert scale and to verify the data. Special care was given to ensure that similar values on the Likert scale from different respondents could be compared. This process of data reduction is necessary to allow systematic and rigorous comparison of intermediate numbers of cases using fsQCA as described in the following section.

\subsection{Analytical approach: fuzzy-set qualitative comparative analysis (fsQCA)}

The intermediate sample size for this study is fourteen cases during the decentralization period and sixteen cases during recentralization due to the creation of two new programs at ACG and ACAT. The sample size and interest in exploring combinations of necessary and sufficient conditions that might lead to self-governance, make fsQCA the best analytical tool available (Ragin, 1987, 2000). In contrast to statistical approaches for which systematic comparison of intermediate sample sizes is a significant challenge - fsQCA uses Bolean algebra to treat cases as configurations of particular conditions and outcomes. Thus, the basis of the explanation is not correlation but set theory (Ragin, 2000). fsQCA is a configurational analytical tool, providing the researcher with a way of contrasting different empirically observed configurations of conditions and outcomes and all of the logically possible configurations of conditions. As a configurational method, it allows the representation of equifinality, which is when a given outcome may result from several different combinations of conditions (Goertz, 2006; Poteete et al., 2010; Ragin, 1987; Rudel, 2005). As such, fsQCA provides the researcher with a list of all of the different configurations of conditions (e.g., multi-level linkages) that are associated with the outcome of interest (e.g., high local autonomy). Associations between conditions and the outcome may or may not establish causal relationships. This is not a property of fsQCA but of the theory or empirical observations underpinning the study. In the context of this study, interviews show that no multi-level linkages were present during the centralization period before 1986. It is only until multi-level linkages are developed during the decentralization period (19861996) that autonomy eventually appears among conservation area programs, suggesting the direction of the relationship (Basurto,
2013). Establishing causal direction for the recentralization period (1998-2006) that followed is not straightforward, however. While there is no reason to think that the previous direction of the relationship had changed, it is also likely that a feedback loop between autonomy and multi-level linkages influenced conservation programs' ability to maintain their autonomy over time.

Finally, by conducting pair-based comparisons, fsQCA establishes conditions of necessity and sufficiency. According to Ragin (2008a), a condition is both necessary and sufficient if it is the only cause that produces an outcome and it is singular (i.e., not a combination of conditions). A condition is sufficient but not necessary if it is capable of producing the outcome but is not the only condition with this capability. A condition is necessary but not sufficient if it is capable of producing an outcome in combination with other conditions and appears in all such combinations. Finally, a condition is neither necessary nor sufficient if it appears only in a subset of the combinations of conditions that produce an outcome. For a more detailed explanation of this approach, see Ragin (2000, 2008b), Rihoux and Ragin (2009) and Schneider and Wagemann (2010), or visit www.compasss.org.

Appendix A presents a detailed account of how the fsQCA analysis was implemented. Comparisons were conducted separately for each different type of multi-level linkage for each time period (i.e., decentralization and recentralization).

\section{Findings}

\subsection{Descriptive trends for the emergence and endurance of local autonomy}

The trends depicted in Fig. 3 show that no conservation area program had autonomy during the early-centralized period, establishing the direction of the relationship between multi-level linkages and autonomy. Local autonomy emerged during the decentralization period, showing varying gains for most conservation area programs, with conspicuous differences between the autonomy that emerged among ACG programs and the rest. These differences might be accounted for by ACG's access and involvement in the design of the decentralization process through informal negotiations with the central government. Interviewees stated that the ACG served as a pilot area for the centralization process during this period. During the recentralization period, some ACG programs lost some autonomy, but the rest of the

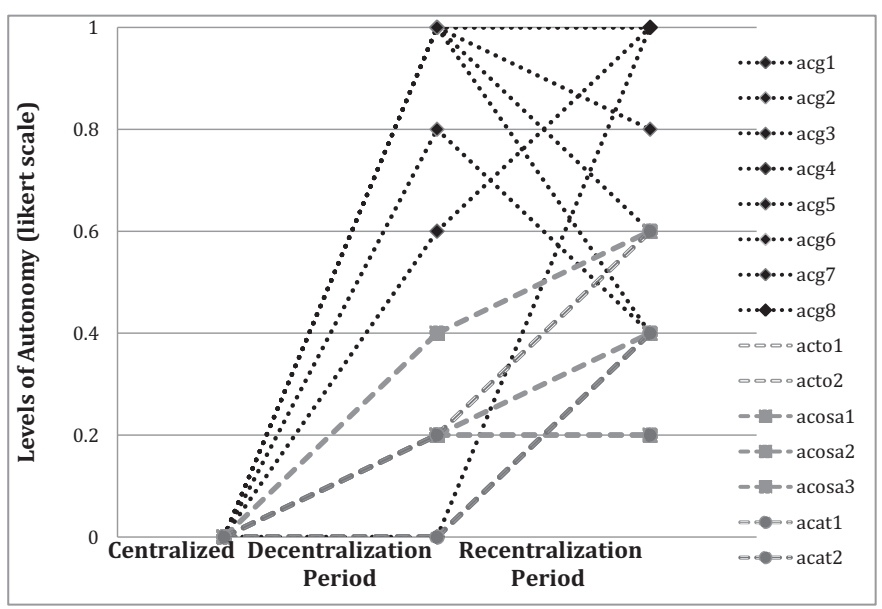

Likert scale: always $=1$, mostly $=0.8$, more often than not $=0.6$, less often than not $=0.4$, rarely $=0.2$, never $=0.0$

Fig. 3. Variation in local autonomy for each conservation area program in three time periods spanning from before 1986 to 2006 . 
Table 2

Percentage of programs per conservation area that attained high autonomy and displayed linkages within each different level and time period. ${ }^{a}$

\begin{tabular}{|c|c|c|c|c|c|c|c|}
\hline \multirow[t]{2}{*}{ Levels } & \multirow[t]{2}{*}{ Cons. areas } & \multicolumn{2}{|c|}{ Centralized } & \multicolumn{2}{|c|}{ Decentralization } & \multicolumn{2}{|c|}{ Recentralization } \\
\hline & & $\%$ & Num. out of total & $\%$ & Num. out of total & $\%$ & Num. out of total \\
\hline \multirow[t]{4}{*}{ Local } & ACG & $0 \%$ & $0 / 2$ & $100 \%$ & $7 / 7$ & $100 \%$ & $8 / 8$ \\
\hline & АCTO & $0 \%$ & $0 / 2$ & $0 \%$ & $0 / 2$ & $50 \%$ & $1 / 2$ \\
\hline & ACOSA & $0 \%$ & $0 / 2$ & $0 \%$ & $0 / 3$ & $0 \%$ & $0 / 3$ \\
\hline & ACAT & $0 \%$ & $0 / 2$ & $0 \%$ & $0 / 2$ & $0 \%$ & $0 / 2$ \\
\hline \multirow[t]{4}{*}{ National } & ACG & $0 \%$ & $0 / 2$ & $100 \%$ & $7 / 7$ & $100 \%$ & $8 / 8$ \\
\hline & АCTO & $0 \%$ & $0 / 2$ & $0 \%$ & $0 / 2$ & $50 \%$ & $1 / 2$ \\
\hline & ACOSA & $0 \%$ & $0 / 2$ & $0 \%$ & $0 / 3$ & $0 \%$ & $0 / 3$ \\
\hline & ACAT & $0 \%$ & $0 / 2$ & $0 \%$ & $0 / 2$ & $0 \%$ & $0 / 2$ \\
\hline \multirow[t]{4}{*}{ International } & ACG & $0 \%$ & $0 / 2$ & $28.5 \%$ & $2 / 7$ & $75 \%$ & $6 / 8$ \\
\hline & ACTO & $0 \%$ & $0 / 2$ & $0 \%$ & $0 / 2$ & $0 \%$ & $0 / 2$ \\
\hline & ACOSA & $0 \%$ & $0 / 2$ & $0 \%$ & $0 / 3$ & $66.6 \%$ & $2 / 3$ \\
\hline & ACAT & $0 \%$ & $0 / 2$ & $0 \%$ & $0 / 2$ & $33.3 \%$ & $1 / 3$ \\
\hline
\end{tabular}

${ }^{a}$ See Appendix A for disaggregated truth tables for each type of level linkage.

programs demonstrated institutional robustness by maintaining or even slightly increasing their autonomy over time. This is consistent with interviews suggesting that the recentralization process was focused on bringing financial equity across all conservation areas and the ACG was the main target of the recentralization effort. The ACG was perceived as having "too much" local financial autonomy, being quite successful at fundraising (Allen, 2001). As a result, the Office of the Comptroller General took an unprecedented, strong oversight role on ACG's accounting procedures. This led to the removal of ACG's locally appointed director and the imposition of a new director from the central government (Basurto, 2013).

Table 2 illustrates that no conservation area showed any type of multi-level linkages during the centralized period. In addition, not all types of linkages (i.e., local, national, and international) had the same effect on each conservation area's ability to gain local autonomy. For instance, within the ACG, highly autonomous programs were associated with the presence of local- and nationallevel linkages during the decentralization period, but not with multi-level linkages at the international level. During this time, the ACG developed a co-management governance regime consisting of seven members drawn in an open process from about nineteen different local, regional, and national institutions, including regional universities, banks, central government's agencies in the region, regional commerce chambers, and local municipal governments). One of the board's main tasks was the hiring of ACG's local director (Basurto, 2013). The ACG also negotiated with the central government administrative autonomy by returning to the central government those civil service positions belonging to personnel working at each of their programs, making it easier to hire and fire personnel (Basurto, 2013). Conservation programs hired inhabitants of surrounding communities, and local businesses were targeted for capital expenditures and regular purchases. These initiatives enjoyed broad support from senior members of the central government and the political and academic elite who, along with ACG staff, view the decentralization project a necessary condition for successful biodiversity conservation in Costa Rica (Basurto, 2013). Interviewees consistently expressed that the purpose of developing local and national linkages rested on the idea that local and national stakeholders needed to view local conservation programs as having a positive impact on their everyday lives.

In contrast, during the recentralization period, strong international linkages providing funding and international recognition led to high levels of autonomy. ACG's recognition by UNESCO as a World Heritage Site provided international recognition that could discourage further attempts by the central government to take away funding and administrative autonomy from conservation area programs. In contrast, ACTOs linkages with numerous large international conservation organizations did not allow them to develop their own technical capacity and thus their programs became dependent on these organizations to operate.

I used fsQCA to disaggregate the data and uncover particular combinations of institutional arrangements at each level (local, national, and international) that were associated with individual conservation area program's ability to achieve local autonomy. Since no program showed any autonomy in the centralized period, the emergence of local autonomy was evaluated in the following time period (decentralization) and its endurance was evaluated during the period of recentralization. For ease of presentation, the technical details of the fsQCA results are presented in Appendix A.

3.2. The influence of multi-level linkages on the emergence of local autonomy during the decentralization period (1986-1998)

Half of the programs $(n=7)$ in the sample were found to be autonomous most of the time, while the other half were found to be autonomous only on rare instances during the decentralization period (Table 3 ). All of the highly autonomous programs were part of the ACG (see Table A4 in Appendix A). Using fsQCA, the following combinations of multi-level linkages led to the emergence of local autonomy among biodiversity conservation programs: (1) At the local level, high local spending, employment, and co-management arrangements were necessary and sufficient conditions for programs to yield high local autonomy. (2) At the national level, it was necessary for programs to have low membership to the civil service. (3) At the international level, conservation areas that developed high international recognition and funding but few partnerships with conservation organizations and few academicoriented partnerships saw the emergence of high local autonomy in their programs.

3.3. Multi-level linkages influencing the endurance of local autonomy in the recentralization period (after 1998-2006)

For the recentralization period, the combination of multi-level linkages that led to high local autonomy was different from the previous time period: (1) at the local level, programs did so through two different combinations of multi-level linkages: either by displaying high local spending and employment, or through having the presence of co-management arrangements. (2) At the national level, programs that displayed high local autonomy did so by having low membership to the civil service or through having high influence in policymaking. (3) At the international level, programs displayed two combinations: either a program had high international recognition and funding and few partnerships with academic 
Table 3

Comparison of combinations of multi-level linkages with conservation area programs showing high and low local autonomy ${ }^{\mathrm{a}}$ during the decentralization period (19861998).

\begin{tabular}{lll}
\hline Levels (1986-1998) & High local autonomy $(n=7)$ & Low local autonomy $(n=7)$ \\
\hline Local & $\begin{array}{l}\text { High local spending, employment, and presence } \\
\text { of co-management arrangements. } \\
\text { Low membership to civil service. }\end{array}$ & $\begin{array}{l}\text { Low local spending, employment, and no co-management arrangements. } \\
\text { National }\end{array}$ \\
$\begin{array}{ll}\text { High international recognition and funding and few } \\
\text { partnerships with academic and conservation organizations. }\end{array}$ & $\begin{array}{l}\text { High international recognition and funding, and many } \\
\text { partnerships with academic and conservation organizations. }\end{array}$ \\
\hline
\end{tabular}

a "High" and "low" verbal labels are used for ease of presentation. Refer to Tables A1, A3, A5 and A6 for raw disaggregated data, truth tables, and tests of consistency, sufficiency, and necessity.

organizations, or it had high international recognition and funding and few partnerships with conservation organizations. Table 4 shows the combinations of multi-level conditions displayed by programs with high and low local autonomy.

\subsection{Comparing combinations of multi-level linkages between time periods}

A direct comparison of multi-level linkages in different time periods indicates that different configurations were important for the emergence of local autonomy versus those important for maintaining its endurance. At the local level, the emergence of the combination of local spending, employment, and local comanagement arrangements was necessary to yield high local autonomy. To maintain their local autonomy, it was sufficient for programs to display high local spending and employment or have the presence of local co-management arrangements (Table 5).

At the national level, having few staff belonging to the civil service was by itself a necessary and sufficient condition for the emergence of local autonomy. In the following time period, however, this condition changed from being necessary and sufficient to only sufficient, because programs that developed high influence in policymaking were also able to reach high local autonomy. Programs also diversified their international-level linkages in relation to the first period. For the decentralization period, having few partnerships with academic and conservation organizations were necessary conditions to develop high local autonomy. Later on, these factors disaggregated into different combinations. Some programs yielded high local autonomy by having few partnerships with academic organizations while

Table 4

Comparison of combinations of multi-level linkages with conservation area programs showing high and low local autonomy ${ }^{\mathrm{a}}$ during the recentralization period (1998-2006).

\begin{tabular}{|c|c|c|}
\hline Levels (1998-2006) & High level of local autonomy $(n=8)$ & Low level of local autonomy $(n=8)$ \\
\hline Local & $\begin{array}{l}\text { High local spending and employment or presence of } \\
\text { co-management arrangements. }\end{array}$ & $\begin{array}{l}\text { Low local spending and local employment. Or, low local } \\
\text { spending despite the presence of local co-management } \\
\text { arrangements. }\end{array}$ \\
\hline National & Low membership to civil service or high perceived influence in policymaking. & High membership to civil service. \\
\hline International & $\begin{array}{l}\text { High international recognition and funding and few partnerships with } \\
\text { academic organizations or conservation organizations. }\end{array}$ & $\begin{array}{l}\text { Low international recognition and funding, and few } \\
\text { partnerships with academic and conservation organizations. } \\
\text { Or, high international funding, many partnerships with } \\
\text { academic and conservation organizations. }\end{array}$ \\
\hline
\end{tabular}

a "High" and "low" verbal labels are used for ease of presentation. Refer to Tables A2, A4, A5 and A6 to find the raw disaggregated data, truth tables, and tests of consistency, sufficiency, and necessity.

Table 5

Comparison of "pathways" or combinations of multi-level interactions linked to the emergence and endurance of local autonomy. ${ }^{\mathrm{a}}$

\begin{tabular}{|c|c|c|}
\hline \multicolumn{3}{|c|}{ Combinations or pathways of multi-level linkages } \\
\hline Levels & For the emergence of local autonomy (1986-1998) & For the endurance of local autonomy (1998-2006) \\
\hline Local & $\begin{array}{l}\text { One pathway: } \\
\text { High local spending } \\
\text { AND } \\
\text { Local employment } \\
\text { AND } \\
\text { Presence of local co-management arrangements }\end{array}$ & $\begin{array}{l}\text { Two pathways: } \\
\text { High local spending } \\
\text { AND } \\
\text { Local employment } \\
\text { OR } \\
\text { Presence of local co-management arrangements }\end{array}$ \\
\hline National & $\begin{array}{l}\text { One pathway: } \\
\text { Low membership to civil service }\end{array}$ & $\begin{array}{l}\text { Two pathways: } \\
\text { Low membership to civil service } \\
\text { OR } \\
\text { High perceived influence in policymaking }\end{array}$ \\
\hline International & $\begin{array}{l}\text { One pathway: } \\
\text { High international recognition and funding } \\
\text { AND } \\
\text { Few partnerships with international academic organizations } \\
\text { AND } \\
\text { Conservation organizations }\end{array}$ & $\begin{array}{l}\text { Two pathways: } \\
\text { High international recognition and funding } \\
\text { AND } \\
\text { Few partnerships with academic organizations } \\
\text { OR } \\
\text { High international recognition and funding } \\
\text { AND } \\
\text { Few partnerships with conservation organizations }\end{array}$ \\
\hline
\end{tabular}

\footnotetext{
${ }^{\text {a }}$ A depiction of the centralization period is not included given that no level linkages were found present in protected area programs before 1986
} 
partnerships with conservation organizations became an irrelevant factor. Other programs needed to have few partnerships with conservation organizations, while partnerships with academic ones became irrelevant in the context of maintaining local autonomy.

\section{Discussion}

Several discussion points emerge from the comparative analysis. First, the same set of multi-level linkages produced different combinations of interactions for the two different processes of institutional change examined in Costa Rica. Only one path (i.e., a combination of multi-level interactions) led to the emergence of institutional change between 1986 and 1998 (Table 5). All of the different linkages within this path constituted necessary and sufficient conditions for autonomy to emerge. The same type and number of combinations was no longer necessary nor sufficient in the following time period or recentralization to maintain local autonomy's endurance. Maintaining the endurance of local autonomy conservation area programs was achieved through two different paths (or combinations of multi-level interactions). These results suggest that institutional diversity might be more important for processes of institutional robustness than for processes of institutional emergence.

Decision-making authority, power, and property rights transferred from the Costa Rican central government to local governance units were the result of informal negotiations between central and local stakeholders. In these settings, it can be expected that the resulting "pathway" or combination of conditions leading to decentralization will be quite narrow or unique. It remains to be seen if the same applies to decentralization processes that are formalized in the law before being implemented.

An increased number of combinations or pathways might develop in situations where local institutions have strong incentives to seek out new linkages in order to retain power and authority, such as within a recentralization environment. In such an environment, increasing multi-level interactions might be a way to compensate for the foregone support previously provided by the central government, in the form of funding, administrative, or political support. Another possibility is that more institutional diversity appeared later in time, simply because local actors had more time to learn and/or design different institutional arrangements among and across levels according to what might best fit their own situational constraints, opportunities, and goals.

Second, analyzing how different configurations of institutional arrangements at different levels may reach similar or different outcomes enables better understanding of the types of institutional arrangements that may complement or conflict with each other, a theoretical issue previously raised by Berkes (2002) and Heikkila et al. (2011). In Costa Rica, high local spending and local employment were necessary but not sufficient; the presence of comanagement was also necessary for the emergence of local autonomy (Table 5). These findings suggest that short- and longterm economic benefits to local inhabitants are not sufficient to lead to the emergence of autonomy of local protected area governance. Power-sharing through decision-making processes is also necessary for local involvement to have positive effects for the autonomy of local protected area governance. Interestingly, once institutional emergence had taken place, some programs could maintain their local autonomy through the presence of comanagement arrangements alone. That is, high local spending and local employment were sufficient (i.e., still important for some programs) but no longer necessary to all programs in maintaining local autonomy over time. Issues of path dependence may be at play here. In localities where local conservation programs might have built local constituencies over a long period of time, the benefits provided to locals might not need to be expressed in terms of high local employment or local purchases. Maintaining support for the autonomy of such local conservation programs from the central government might be enough through involvement in decision-making processes.

Another example: during the decentralization phase, having low membership by employees to the civil service was necessary for the emergence of local autonomy. Later on, however, programs developed an alternative path or interaction at the national level with which to maintain their local autonomy. Programs were also able to maintain high local autonomy through influencing central government's policies (Table 5). But no programs with high membership of employees in the civil service developed high local autonomy (Tables 3 and 4 ). These findings suggest that in the Costa Rican biodiversity conservation context, there are factors within the civil service precluding personnel within conservation areas to perceive clear benefits from pursuing forms of local autonomy for the benefit of their biodiversity conservation mission. As described in depth elsewhere (Basurto, 2013), ACG programs avoided this situation by developing alternative institutional arrangements for employing its personnel outside the civil service. They succeeded because employees could be given credible assurances that their job security, retirement package, and benefits would be essentially the same as employees with civil service protection. These assurances came from developing linkages with the international community, in the form of high recognition and funding, and from local stakeholders, in the form of trust that employees had on their governance structure, based on co-management agreements with locals who have high reputations within the local community (Allen, 2001; Basurto, 2013).

From a theoretical stance, the above examples also illustrate one way we can keep track of different multi-level linkages as conditions of necessity or sufficiency for a particular outcome, and how sufficiency and necessity relationships are not static but may change over time. This is relevant for scholars' ability to develop a better theoretical basis to explain how causal linkages among factors that influence successful collective action influence each other in particular contexts of interest.

Finally, the analysis of the Costa Rican setting suggests that apart from the ACG, the twenty-year-long (1986-2006) reform process of the conservation area system has had a limited impact on facilitating local autonomy to conservation areas - at least as it relates to biodiversity conservation-related activities. Only the ACG took significant advantage of the decentralization process allowed by the central government, particularly to involve locals in the governance of the conservation area (Basurto, 2013). Similarly, the recentralization effort by the central government was not generalized toward all conservation areas or programs within conservation areas. It mainly affected only particular programs within the ACG, but their losses of autonomy were not severe (see Table 2). The nuanced description of the historic and political events that shaped these processes in Costa Rica is provided in Basurto (2013) and Basurto and Jimenez (2013), and is beyond the scope of this paper.

\section{Conclusion}

This paper sought to advance CPR theory by furthering our understanding of how processes of institutional change can be mediated by multi-level institutional arrangements. The findings are consistent with the empirical work of other scholars, like Rudel (2005), who suggests that configurational analyses could be useful to formalize the study of how similar factors might combine and affect resource management outcomes in different ways, depending on the particulars of the local context. 
As CPR scholars move to better incorporate the role of multilevel interactions into the study of local institutions, they need to avoid the tendency to search for "the" necessary conditions for successful local collective action, and instead look for configurations of necessary and sufficient conditions in particular contexts. This study highlighted the combinatorial and complex nature of multi-level linkages associated with processes of institutional change. The procedure described here suggests that the study of combinations of conditions can be manageable and insightful. For instance, in the context of biodiversity conservation in Costa Rica, we learned that the same set of multi-level linkages associated with the emergence of local autonomy combined differently than when they were associated with maintaining its endurance (Table 5). It was also possible to differentiate between combinations of multi-level linkages by their relative importance and/or learn how particular configurations of institutional arrangements at different levels between actors or organizations can complement or conflict with each other.

Finally, as scholars further characterize CPRs as socialecological systems, and further develop a multi-tiered hierarchical framework, comparisons of cases with explicit multi-level linkages will become more apparent. As deeper tiers of the framework are developed and become more specialized (Basurto et al., 2013), the search for commonalities among cases in specialized tiers might require analytical techniques that can deal with the kinds of issues discussed above. Scholars developing such a framework will also need to address the challenge of comparing intermediate sample sizes. The system studied here dealt with a similar challenge. Using conservation area programs as the unit of analysis, this study sampled $46 \%(n=16)$ of the total number of programs active for biodiversity conservation in Costa Rica. Even if the total universe of programs had been surveyed $n \approx 40$, the comparative challenge for a statistical approach would have remained. At the same time, there is the need to continue to better develop how fsQCA can be used effectively with qualitative-based data (Basurto and Speer, 2012), particularly since increasing the comparability of case study research will better inform the development of a robust framework for the analysis of sustainable social-ecological systems.

\section{Acknowledgements}

Funding for this research was provided by the Mexican Funding Agency CONACyT, the Mulago Foundation, and the Research Wallace Foundation. I am grateful to Wibke Crewett, Morgan Gopnik, Rebecca Gruby, Roger Madrigal, Kirby Rootes-Murdy, and Johanna Speer for their valuable comments on earlier versions of this manuscript. Many thanks to Patty Lezotte for her excellent editing suggestions.

\section{Appendix A. Description of the fsQCA procedure}

Standard QCA software (Ragin, 2008a) aided the analysis of necessity and sufficiency of multi-level conditions that affected the emergence of local autonomy (AUTON). The analysis was conducted for each type of level (i.e., local, national, international). At the local level, the analysis was performed for local communal involvement (EMPLOY), local direct spending (SPEND), and co-management with local or regional stakeholders (COMGT). At the national level, the analysis included the degree of influence of national civil service policies (CISERV) and national participation in policymaking (POLIMAKE). At the international level, the multi-level linkages were academic-oriented partnerships (RESEAR), conservation-oriented partnerships (CONSERV), and direct support by development aid organizations (DEVAID). For each level linkage, an analysis of necessity was conducted first. A condition is necessary but not sufficient if it is capable of producing an outcome in combination with other conditions and appears in all such combinations (Ragin, 2008a).

Tables A1 and A2 display the raw fuzzy-set scores for each of the two time periods analyzed: decentralization/emergence of local autonomy and recentralization/endurance of local autonomy. These scores resulted from the average value of all of its measures. Tables A3 and $\mathrm{A} 4$ provide the truth tables for interactions at each level with local programs per time period. In QCA parlance, a truth table is a matrix of all logically possible combinations of the conditions. In Tables A3 and A4, only those combinations with empirical instances are shown, where 0 is absence and 1 is presence. Following Ragin (2008b), consistency cutoff values were chosen by following natural breaks in the data. Recall that consistency values range from 1 to 0 , and in crisp sets (measuring only presence or absence instead of degree of presence and absence, as is done with fuzzy-sets) measures the proportion of cases in a given row that display the outcome in question. In fuzzy-sets, consistency measures the membership scores of the conditions that are a subset of the outcome. The higher the value of consistency, the more cases or membership scores in the row that agree in displaying the outcome. The lower the value of consistency, the fewer cases or membership scores agree on displaying the particular combinations of conditions and the outcome of interest. Thus, the measure of consistency is also used as an initial test of how well the model has been specified. That is, the conditions chosen are relevant to the outcome in question. In general, the consistency scores obtained in this study are quite high because the appropriateness of the factors to be studied was assessed through an iterative process informed by theory predictions and direct field

Table A1

Fuzzy-set values of all conditions and the outcome: emergence of local autonomy (time period of decentralization 1986-1998).

\begin{tabular}{|c|c|c|c|c|c|c|c|c|c|}
\hline \multirow[t]{2}{*}{ Cases } & \multirow{2}{*}{$\begin{array}{l}\text { Outcome } \\
\text { AUTON }\end{array}$} & \multicolumn{8}{|c|}{ Conditions } \\
\hline & & EMPLOY & SPEND & COMGT & CISERV & POLIMAKE & RESEAR & CONSERV & DEVAID \\
\hline acg1 & 0.6 & 0.8 & 1.0 & 1.0 & 0.0 & 1.0 & 1.0 & 0.7 & 1.0 \\
\hline acg2 & 1.0 & 0.8 & 1.0 & 1.0 & 0.2 & 0.2 & 0.6 & 0.2 & 0.7 \\
\hline acg3 & 1.0 & 0.8 & 1.0 & 1.0 & 0.2 & 1.0 & 0.6 & 0.2 & 1.0 \\
\hline $\operatorname{acg} 4$ & 1.0 & 0.6 & 1.0 & 1.0 & 0.2 & 1.0 & 0.8 & 0.2 & 0.9 \\
\hline acg5 & 0.8 & 0.8 & 1.0 & 1.0 & 0.0 & 0.0 & 0.6 & 0.2 & 0.4 \\
\hline acg6 & 1.0 & 0.8 & 1.0 & 1.0 & 0.2 & 1.0 & 0.2 & 0.2 & 0.7 \\
\hline $\operatorname{acg} 7$ & 1.0 & 0.6 & 1.0 & 1.0 & 0.0 & 0.0 & 0.2 & 0.2 & 1.0 \\
\hline acto1 & 0.0 & 0.4 & 0.4 & 0.4 & 1.0 & 1.0 & 0.6 & 0.8 & 0.9 \\
\hline acto2 & 0.0 & 0.4 & 0.4 & 0.2 & 1.0 & 0.0 & 1.0 & 0.8 & 0.9 \\
\hline acosa1 & 0.2 & 0.4 & 0.4 & 0.0 & 1.0 & 0.0 & 0.6 & 0.3 & 0.4 \\
\hline acosa2 & 0.2 & 0.4 & 0.4 & 0.4 & 1.0 & 0.0 & 1.0 & 0.4 & 0.8 \\
\hline acosa3 & 0.4 & 0.4 & 0.4 & 0.0 & 1.0 & 0.0 & 1.0 & 0.2 & 0.8 \\
\hline acat1 & 0.2 & 0.4 & 0.4 & 0.2 & 1.0 & 0.0 & 0.4 & 0.1 & 0.4 \\
\hline acat2 & 0.2 & 0.4 & 0.4 & 0.4 & 1.0 & 0.0 & 0.4 & 0.8 & 0.6 \\
\hline
\end{tabular}


Table A2

Fuzzy-set values of all conditions and the outcome: endurance of local autonomy (time period of recentralization 1998-2006).

\begin{tabular}{|c|c|c|c|c|c|c|c|c|c|}
\hline \multirow[t]{2}{*}{ Cases } & \multirow{2}{*}{$\begin{array}{l}\text { Outcome } \\
\text { AUTON }\end{array}$} & \multicolumn{8}{|c|}{ Conditions } \\
\hline & & EMPLOY & SPEND & COMGT & CISERV & POLIMAKE & RESEAR & CONSERV & DEVAID \\
\hline $\operatorname{acg} 1$ & 1.0 & 1.0 & 1.0 & 1.0 & 0.0 & 0.2 & 1.0 & 0.0 & 1.0 \\
\hline acg2 & 0.4 & 1.0 & 0.6 & 1.0 & 0.2 & 0.2 & 0.4 & 0.0 & 0.1 \\
\hline acg3 & 0.8 & 1.0 & 0.8 & 1.0 & 0.2 & 0.8 & 0.6 & 0.0 & 0.9 \\
\hline $\operatorname{acg} 4$ & 1.0 & 1.0 & 0.6 & 1.0 & 0.2 & 1.0 & 1.0 & 0.0 & 1.0 \\
\hline acg5 & 0.4 & 1.0 & 0.4 & 1.0 & 0.0 & 0.0 & 0.4 & 0.0 & 0.2 \\
\hline acg6 & 0.6 & 1.0 & 0.6 & 1.0 & 0.2 & 0.8 & 0.2 & 0.0 & 0.7 \\
\hline acg7 & 1.0 & 0.4 & 1.0 & 1.0 & 0.0 & 0.0 & 0.2 & 0.6 & 0.8 \\
\hline acg8 & 1.0 & 1.0 & 1.0 & 0.0 & 0.0 & 0.0 & 1.0 & 0.1 & 0.7 \\
\hline acto1 & 0.4 & 0.4 & 0.4 & 0.6 & 1.0 & 0.0 & 0.6 & 0.7 & 0.9 \\
\hline acto2 & 0.4 & 0.4 & 0.4 & 0.2 & 1.0 & 0.8 & 1.0 & 0.7 & 0.9 \\
\hline acosa 1 & 0.4 & 0.2 & 0.4 & 0.2 & 1.0 & 0.0 & 0.6 & 0.9 & 0.7 \\
\hline acosa2 & 0.2 & 0.4 & 0.4 & 0.4 & 1.0 & 0.0 & 1.0 & 0.4 & 0.8 \\
\hline acosa3 & 0.6 & 0.4 & 0.4 & 0.0 & 1.0 & 0.0 & 0.8 & 0.3 & 0.9 \\
\hline acat1 & 0.2 & 0.4 & 0.4 & 0.2 & 1.0 & 0.0 & 0.4 & 0.1 & 0.2 \\
\hline acat2 & 0.6 & 0.4 & 0.4 & 0.4 & 0.8 & 0.0 & 0.6 & 0.9 & 0.6 \\
\hline acat3 & 0.4 & 0.4 & 0.4 & 0.0 & 1.0 & 0.0 & 0.4 & 0.3 & 0.6 \\
\hline
\end{tabular}

observations and interviews. QCA best practices recommend setting the threshold of consistency between 0.9 and 0.8 , a rigorous level to assure that the combinations of conditions are reliably related to the outcome of interest. There are exceptions to this threshold, particularly when the data present clear breaks and case knowledge can inform the decision for the adoption of a given threshold. This criterion was used for the data set in Tables A4.1 and A4.2. Table A5 provides consistency values for the necessity of multi-level linkages for the presence or absence of the outcome.

Tables A6 and A7 provide tests for the sufficiency of combinations for both time periods and for the solution consistency and coverage values. A condition is sufficient but not necessary if it is capable of producing the outcome, but is not the only condition with this capability (Ragin, 2008a). Coverage tells us how much of the outcome (e.g., local autonomy) is explained by a given combination of conditions (e.g., multi-level linkages). It is, therefore, given as a proportion of membership scores ranging from 1 to 0 (Ragin, 2008a). In Table A7, coverage is expressed for the entire solution (i.e., all the combinations of multi-level linkages with which programs maintained their local autonomy), and as unique coverage, which expresses the proportion of membership scores covered by a given configuration without being overlapped by any other configuration. By viewing configurations as paths toward a certain outcome, unique coverage can be thought of as the proportion of cases or membership scores that uniquely traveled that path toward the outcome. Finally, results on Tables A6 and A7 display the intermediate solution. As of the time of analyzing this data, fsQCA software provided three different standard analyses options: complex, parsimonious, and intermediate solutions. Results are presented for the intermediate solution, which allows the software to conduct "counterfactual

Table A3

Truth tables for the analysis of sufficiency for the emergence of local autonomy at each level (i.e., local, national, international) and type of interaction or condition (i.e., EMPLOY, SPEND, COMGT, CISERV, POLIMAKE, RESEAR, CONSERV, DEVAID).

\begin{tabular}{|c|c|c|c|c|c|c|}
\hline \multicolumn{7}{|c|}{ A3.1. Local level ${ }^{a}$} \\
\hline \multicolumn{3}{|c|}{ Conditions } & \multirow[t]{2}{*}{ Number } & \multirow{2}{*}{$\begin{array}{l}\text { Outcome } \\
\text { AUTON }\end{array}$} & \multirow[t]{2}{*}{ Consist. } & \multirow[t]{2}{*}{ Cases } \\
\hline EMPLOY & SPEND & COMGT & & & & \\
\hline 1 & 1 & 1 & 7 & 1 & 0.824 & ACG1, ACG2, ACG3, ACG4, ACG5, ACG6, ACG7 \\
\hline 0 & 0 & 0 & 7 & 0 & 0.286 & ACTO1, АCTO2, ACOSA1, ACOSA2, ACOSA3, ACAT1, ACAT2 \\
\hline \multicolumn{7}{|c|}{ A3.2. National level ${ }^{\mathrm{b}}$} \\
\hline \multicolumn{2}{|c|}{ Conditions } & & \multirow[t]{2}{*}{ Number } & Outcome & \multirow[t]{2}{*}{ Consist. } & \multirow[t]{2}{*}{ Cases } \\
\hline CISERV & POLII & & & AUTON & & \\
\hline 0 & 0 & & 3 & 1 & 0.929 & ACG2, ACG5, ACG7 \\
\hline 0 & 1 & & 4 & 1 & 0.889 & ACG1, ACG3, ACG4, ACG6 \\
\hline 1 & 1 & & 1 & 0 & 0.444 & ACTO1 \\
\hline 1 & 0 & & 6 & 0 & 0.226 & ACTO2, ACOSA1, ACOSA2, ACOSA3, ACAT1, ACAT2 \\
\hline
\end{tabular}

A3.3. International level ${ }^{\mathrm{b}}$

\begin{tabular}{llllll}
\hline Conditions & & & Number & Outcome & Consist. \\
\hline RESEAR & CONSERV & DEVAID & & AUTON & ACG6, ACG7 \\
\hline 0 & 0 & 1 & 2 & 1 & 0.854 \\
1 & 0 & 0 & 2 & 0 & 0.733 \\
1 & 0 & 1 & 5 & 0 & 0.729 \\
0 & 0 & 0 & 1 & 0 & 0.708 \\
0 & 1 & 1 & 1 & 0 & 0.654 \\
1 & 1 & 1 & 3 & ACOSA2, ACG5 & ACAT1 \\
\hline
\end{tabular}

a Set at consistency 0.80 cutoff due to natural break in the data.

b Set at consistency 0.85 cutoff due to natural break in the data. 
Table A4

Truth tables for the analysis of sufficiency for the endurance of local autonomy at each level (i.e., local, national, international) and type of interaction or condition (i.e., EMPLOY, SPEND, COMGT, CISERV, POLIMAKE, RESEAR, CONSERV, DEVAID).

\begin{tabular}{|c|c|c|c|c|c|c|}
\hline \multicolumn{7}{|c|}{ A4.1. Local level ${ }^{\mathrm{a}}$} \\
\hline \multicolumn{3}{|c|}{ Conditions } & \multirow[t]{2}{*}{ Number } & \multirow{2}{*}{$\begin{array}{l}\text { Outcome } \\
\text { AUTON }\end{array}$} & \multirow[t]{2}{*}{ Consist. } & \multirow[t]{2}{*}{ Cases } \\
\hline EMPLOY & SPEND & COMGT & & & & \\
\hline 1 & 1 & 1 & 5 & 1 & 0.935 & ACG1, ACG2, ACG3, ACG4, ACG6 \\
\hline 0 & 1 & 1 & 1 & 1 & 0.917 & ACG7 \\
\hline 1 & 1 & 0 & 1 & 1 & 0.900 & ACG8 \\
\hline 1 & 0 & 1 & 1 & 1 & 0.895 & ACG5 \\
\hline 0 & 0 & 1 & 1 & 1 & 0.800 & АCT01 \\
\hline 0 & 0 & 0 & 7 & 0 & 0.696 & $\begin{array}{l}\text { ACTO2, ACOSA1, ACOSA2, } \\
\text { ACOSA3, ACAT1, ACAT2, ACAT3 }\end{array}$ \\
\hline \multicolumn{7}{|c|}{ A4.2. National level ${ }^{\mathrm{b}}$} \\
\hline \multicolumn{2}{|c|}{ Conditions } & & \multirow[t]{2}{*}{ Number } & Outcome & \multirow[t]{2}{*}{ Consist. } & \multirow[t]{2}{*}{ Cases } \\
\hline CISERV & POLIMAKE & & & AUTON & & \\
\hline 0 & 1 & & 3 & 1 & 0.929 & ACG3, ACG4, ACG6 \\
\hline 0 & 0 & & 5 & 1 & 0.808 & ACG1, ACG2, ACG5, ACG7, ACG8 \\
\hline 1 & 1 & & 1 & 1 & 0.75 & АCTO2 \\
\hline 1 & 0 & & 7 & 0 & 0.474 & $\begin{array}{l}\text { ACTO1, ACOSA1, ACOSA2, } \\
\text { ACOSA3, ACAT1, ACAT2, ACAT3 }\end{array}$ \\
\hline \multicolumn{7}{|c|}{ A4.3. International level ${ }^{\mathrm{c}}$} \\
\hline \multicolumn{3}{|c|}{ Conditions } & \multirow[t]{2}{*}{ Number } & Outcome & \multirow[t]{2}{*}{ Consist. } & \multirow[t]{2}{*}{ Cases } \\
\hline RESEAR & CONSERV & DEVAID & & AUTON & & \\
\hline 0 & 1 & 1 & 1 & 1 & 1.000 & ACG7 \\
\hline 1 & 0 & 1 & 6 & 1 & 0.925 & $\begin{array}{l}\text { ACG1, ACG3, ACG4, ACG8, } \\
\text { ACOSA2, ACOSA3 }\end{array}$ \\
\hline 0 & 0 & 1 & 2 & 1 & 0.909 & ACG6, ACAT3 \\
\hline 1 & 1 & 1 & 4 & 0 & 0.769 & ACOSA1, АCAT2, АCTO1, АСТО2 \\
\hline 0 & 0 & 0 & 3 & 0 & 0.750 & ACG2, ACG5, ACAT1 \\
\hline
\end{tabular}

a Set at consistency 0.79 cutoff due to natural break in the data.

b Set at consistency 0.74 cutoff due to natural break in the data.

c Set at consistency 0.85 cutoff due to natural break in the data.

analyses based on information about causal conditions supplied by the user" (Ragin, 2008a). Given the theoretical and substantive knowledge available about the cases, this was an appropriate standard analysis to choose. In addition, fsQCA's software ability to conduct counterfactual analyses is thought to be one of the main strengths of this analytical technique (Ragin, 2008a). Counterfactual analysis has a long tradition within the social sciences and consists of evaluating the plausibility - given theoretical and substantive contextual knowledge - of a combination of factors that lacks empirical instances (Hicks et al., 1995, cited in Ragin, 2008b). Finally, Tables A6 and A7 follow standard notation in fsQCA where " " represents the negation of a given condition, “*” is Boolean multiplication or the logical "AND", and "+" is Boolean addition or the logical "OR." Recall that Boolean multiplication, like Boolean addition, is not arithmetic (Ragin, 2008a).

\section{Appendix B. Description of the criteria to identify and define linkages}

Based on the general definition of linkage used in this study, as a formal rule, strategy, or regularized action that establishes interdependencies among two distinct actors around different tasks (Heikkila et al., 2011), a rationale was developed to define particular types of linkages described below:

\section{B.1. Local-level linkages}

Linkage: Local communal involvement through direct employment (EMPLOY).

Rationale: Employment of members of surrounding communities to the protected area constitutes a regularized action that

Table A5

Consistency values for the necessity of each type of linkage for the presence or absence of the outcome (i.e., local autonomy).

\begin{tabular}{|c|c|c|c|c|}
\hline \multirow[t]{3}{*}{ Types of linkage } & \multicolumn{2}{|c|}{ Emergence of high local autonomy } & \multicolumn{2}{|c|}{ Endurance of high local autonomy } \\
\hline & Presence & Absence & Presence & Absence \\
\hline & Consistency cutoff 0.85 & Consistency cutoff 0.85 & Consistency cutoff 0.85 & Consistency cutoff 0.85 \\
\hline EMPLOY & 0.82 & 0.72 & 0.87 & 0.67 \\
\hline SPEND & 1.00 & 0.66 & 0.91 & 0.91 \\
\hline COMGT & 0.92 & 0.75 & 0.72 & 0.67 \\
\hline CISERV & 0.26 & 0.09 & 0.43 & 0.30 \\
\hline POLIMAKE & 0.50 & 0.78 & 0.34 & 0.91 \\
\hline RESEAR & 0.63 & 0.34 & 0.85 & 0.67 \\
\hline CONSERV & 0.36 & 0.59 & 0.36 & 0.76 \\
\hline DEVAID & 0.86 & 0.38 & 0.89 & 0.61 \\
\hline
\end{tabular}

Numbers at or above the cutoff threshold are highlighted in bold. 
Table A6

Tests for the analysis of sufficiency for the emergence of local autonomy.

\begin{tabular}{lll}
\hline Level & Presence & Absence \\
\hline Local & Intermediate solution & Intermediate solution \\
& Sol. Coverage: 0.736 & Sol. Coverage: 0.656 \\
& Sol. Consistency: 0.823 & Sol. Consistency: 1.00 \\
& Solution: & Solution: \\
& COMGT*SPEND*EMPLOY & $\sim$ COMGT* $\sim$ SPEND* $\sim$ EMPLOY \\
& Intermediate solution & Intermediate solution \\
National & Sol. Coverage: 0.736 & Sol. Coverage: 0.750 \\
& Sol. Consistency: 0.903 & Sol. Consistency: 0.774 \\
& Solution: & Solution: \\
& $\sim$ CISERV & $\sim$ POLIMAKE*CISERV \\
& Intermediate solution & Intermediate solution \\
& Sol. Coverage: 0.460 & Sol. Coverage: 0.531 \\
& Sol. Consistency: 0.854 & Sol. Consistency: 0.723 \\
& Solution: & Solution \\
& DEVAID* CONSERV* $\sim$ RESEAR & DEVAID*CONSERV*RESEAR \\
\hline
\end{tabular}

Table A7

Tests for the analysis of sufficiency for the endurance of local autonomy.

\begin{tabular}{|c|c|c|}
\hline Level & Presence & Absence \\
\hline Local & $\begin{array}{l}\text { Intermediate solution } \\
\text { Sol. Coverage: } 0.936 \\
\text { Sol. Consistency: } 0.786 \\
\text { Solution: } \\
\text { COMGT } \\
\text { Unique Coverage: } 0.106 \\
\text { Consistency: } 0.756 \\
\text { SPEND*EMPLOY } \\
\text { Unique Coverage: } 0.213 \\
\text { Consistency: } 0.929\end{array}$ & $\begin{array}{l}\text { Intermediate solution } \\
\text { Sol. Coverage: } 0.940 \\
\text { Sol. Consistency: } 0.633 \\
\text { Solution: } \\
\text { COMGT } \\
\text { Unique Coverage: } 0.030 \\
\text { Consistency: } 0.629 \\
\sim \text { SPEND } \\
\text { Unique Coverage: } 0.242 \\
\text { Consistency: } 0.882 \\
\text { EMPLOY } \\
\text { Unique Coverage: } 0.000 \\
\text { Consistency: } 0.786\end{array}$ \\
\hline National & $\begin{array}{l}\text { Intermediate solution } \\
\text { Sol. Coverage: } 0.723 \\
\text { Sol. Consistency: } 0.810 \\
\text { Solution: } \\
\sim \text { CISERV } \\
\text { Unique Coverage: } 0.723 \\
\text { Consistency: } 0.810 \\
\text { POLIMAKE } \\
\text { Unique Coverage: } 0.064 \\
\text { Consistency: } 0.842\end{array}$ & $\begin{array}{l}\text { Intermediate solution } \\
\text { Sol. Coverage: } 0.818 \\
\text { Sol. Consistency: } 0.63 \\
\text { Solution: } \\
\text { CISERV }\end{array}$ \\
\hline International & $\begin{array}{l}\text { Intermediate solution } \\
\text { Sol. Coverage: } 0.862 \\
\text { Sol. Consistency: } 0.900 \\
\text { Solution: } \\
\text { DEVAID* } \sim \text { RESEAR } \\
\text { Unique Coverage: } 0.117 \\
\text { Consistency: } 0.931 \\
\text { DEVAID* CONSERV } \\
\text { Unique Coverage: } 426 \\
\text { Consistency: } 0.886\end{array}$ & $\begin{array}{l}\text { Intermediate solution } \\
\text { Sol. Coverage: } 0.894 \\
\text { Sol. Consistency: } 0.766 \\
\text { Solution: } \\
\sim \text { CONSERV* } \sim \text { RESEAR } \\
\text { Unique Coverage: } 0.394 \\
\text { Consistency: } 0.787 \\
\text { DEVAID*CONSERV } \\
\text { Unique Coverage: } 0.333 \\
\text { Consistency: } 0.7333\end{array}$ \\
\hline
\end{tabular}

establishes interdependency between members of the protected area and the surrounding communities. Both actors can benefit from the protected areas' level of autonomy in determining their local agenda for biodiversity conservation. If and when that is the case, local communities can become a political resource to the protected area by supporting the protected area's claims for local autonomy, thereby effectively modifying the political costs to the central government from taking or granting local autonomy to the protected area.

Linkage: Local direct spending (SPEND).

Rationale: Local direct spending constitutes a regularized action that establishes interdependency between members of the protected area and members of the local or regional business community. Both actors can benefit from the protected areas' level of autonomy in determining their local agenda for biodiversity conservation. If and when that is the case, local or regional businesses can become a political resource to the protected area by supporting the protected area's claims for local autonomy, thereby effectively modifying the political costs to the central government from taking or granting local autonomy to the protected area.

Linkage: Co-management with local or regional stakeholders (COMGT).

Rationale: Involvement of local or regional stakeholders in decision-making processes regarding the governance of the protected area establishes interdependency between members of the protected area and members of the local or regional oligarchy. Both actors can benefit from the protected areas' level of autonomy in determining their local agenda for biodiversity conservation. If and when that is the case, local or regional leaders can become a political resource to the protected area by supporting the protected area's claims for local autonomy, thereby effectively modifying the political costs to the central government from taking or granting local autonomy to the protected area.

\section{B.2. National-level linkages}

Linkage: Degree of influence of national civil service policies (CISERV).

Rationale: National civil service policies influence the amount of control that protected areas have over their own personnel, including hiring and firing. Influence on how national civil service policies are shaped constitutes a particular type of interdependency between protected areas and the central government where bargaining between both takes place. The resultant outcome affects the protected areas' degree of operational autonomy.

Linkage: National participation in policymaking (POLIMAKE). Rationale: Participation in national policymaking about the protected areas' governance issues creates interdependency between protected areas and the central government where bargaining between both takes place. The resultant outcome affects the protected areas' degree of operational autonomy.

\section{B.3. International-level linkages}

Linkage: Research-oriented partnerships (RESEAR). Rationale: Academic or research-oriented partnerships between the protected area and international research organizations, such as universities, create interdependencies that can align both actors' interests in maintaining or increasing the protected areas' local autonomy. This interdependency can yield financial or political support to the protected area, most often in the form of either funding that can be used by the protected area to counterbalance the central government's control of local budgets, or by providing political support, by pressuring the central government with mobilizing resources at the international level if protected area issues or demands are not met. Linkage: Conservation-oriented partnerships (CONSERV). Rationale: Conservation-oriented partnerships between the protected area and international conservation organizations create interdependencies that can align both actors' interests in maintaining or increasing the protected areas' local autonomy. This interdependency can yield financial or political support to the protected area, most often either in the form of funding that can be used by the protected area to counterbalance the central government's control of local budgets, or by providing political 
support by pressuring the central government with mobilizing resources at the international level if protected area issues or demands are not met.

\section{Linkage: Direct support by development aid organizations (DEVAID).}

Rationale: Development aid-oriented partnerships between the protected area and the international development organizations create interdependencies that can align both actors' interests in maintaining or increasing the protected areas' local autonomy. This interdependency can yield financial or political support to the protected area, most often in the form of either funding that can be used by the protected area to counterbalance the central government's control of local budgets, or by providing political support by pressuring the central government to withhold future support to the country.

\section{References}

ACG (Area de Conservacion Guanacaste), 1991. Estrategia de Desarrollo. Documento en Análisis. Minerem, Guanacaste, Costa Rica.

Adger, W.N., Brown, K., Tompkins, E.L., 2005. The political economy of cross-scale networks in resource co-management. Ecology and Society 10

Agrawal, A., 2002. Common resources and institutional sustainability. In: Ostrom, E., Dietz, T., Dolšak, N., Stern, P.C., Stonich, S., Weber, E. (Eds.), The Dramma of the Commons. National Academies Press, Washington, DC.

Allen, W.H., 2001. The Green Phoenix: Restoring the Tropical Forests of Guanacaste Costa Rica. Oxford University Press, UK.

Anderies, J.M., Janssen, M.A., Ostrom, E., 2004. A framework to analyze the robustness of social-ecological systems from an institutional perspective. Ecology and Society 9.

Arguedas, S., 2002. Estudio Rápido de Manejo para una Muestra de 19 Áreas Protegidas Gerencialmente Fuertes de Costa Rica, Reporte para Wildlife Conservation Society, San José, Costa Rica.

Arguedas, S., Rodríguez, J.M., 2003. Algunas Lecciones Aprendidas: Sistema de Áreas Protegidas de Costa Rica (Borrador Final). ELAP, WCS, San José, Costa Rica.

Axelrod, R., 1984. The Evolution of Cooperation. Basic Books, New York.

Baland, J., Platteau, J., 1996. Halting Degradation of Natural Resources: Is There a Role for Rural Communities? Oxford University Press, Oxford, UK.

Basurto, X., 2013. Analyzing protected area bureaucratic institutions to understand barriers to local participation in biodiversity conservation: the Costa Rican example. Conservation and Society.

Basurto, X., Gelcich, S., Ostrom, E., 2013. The social-ecological systems framework as a knowledge classificatory system for benthic small-scale fisheries. Working Paper. Duke Marine Lab, Beaufort, NC

Basurto, X., Jimenez, I., 2013. Institutional arrangements for adaptive governance of biodiversity conservation: the experience of the Area de Conservación de Guanacaste, Costa Rica. Journal of Latin American Geography 12, 111-133.

Basurto, X., Speer, J., 2012. Fostering the dialogue between theory and field observations through formalizing the transition of interview data to fuzzy sets. Journal of Field Methods 24, 144-174.

Berkes, F. (Ed.), 1989. Common Property Resources: Ecology and CommunityBased Sustainable Development. Belhaven Press, London, UK.

Berkes, F., 2002. Cross-scale institutional linkages: perspectives from the bottom up. In: Ostrom, E., Dietz, T., Dolšak, N., Stern, P.C., Stonich, S., Weber, E. (Eds.), The Dramma of the Commons. National Academies Press, Washington, DC

Berkes, F., George, P.J., Preston, R.J., 1991. Co-management: the evolution in theory and practice of the joint administration of living resources. Alternatives 18 , $12-18$.

Bermudez, G.V., 1990. Curso-Taller Sobre Administración: Unidades Regionales de Conservación, Workshop on Regional Conservation Units, Unidad Regional de Conservación Guanacaste, Santa Rosa, Guanacaste, Costa Rica.

Boza, M.A., Jukofsky, D., Wille, C., 1995. Costa-Rica is a laboratory, not ecotopia. Conservation Biology 9, 684-685.

Buchanan, J.M., Tullock, G., 1962. The Calculus of Consent: Logical Foundations of Constitutional Democracy. University of Michigan Press, Ann Arbor, MI.

Cash, D.W., Adger, W.N., Berkes, F., Garden, P., Lebel, L., Olsson, P., Pritchard, L., Young 0,2006 . Scale and cross-scale dynamics: governance and information in a multilevel world. Ecology \& Society 11, 181-192.

Chowdhury, M.S.H., Koike, M., 2010. An overview on the protected area system for forest conservation in Bangladesh. Journal of Forestry Research (Harbin) 21, 111-118.

Commons, J.R., 1924. Legal Foundations of Capitalism. Macmillan, New York.

Cox, M., 2011. Advancing the diagnostic analysis of environmental problems. International Journal of the Commons 5, 346-363.

Cox, M., Arnold, G., Tomas, S.V., 2010. A review of design principles for communitybased natural resource management. Ecology and Society 15, 38 http://www.ecologyandsociety.org/vol15/iss4/art38/ (online).

Durán, O., Sánchez, J.M., 1989. Alcances del Proceso de Implementación del Esquema Organizativo del Sistema Nacional de Areas de Conservación,
MINEREM-SPN-OTS-FPN Workshop, La Selva Biological Station, Puerto Viejo de Sarapiquí, Costa Rica.

Evans, S., 1999. The Green Republic: A Conservation History of Costa Rica. University of Texas Press, Austin, TX

García, R., 1996. Propuesta Técnica de Ordenamiento Territorial con fines de Conservación de Biodiversidad: Proyecto Grúas, Informe de País: Costa Rica Proyecto Corredor Biológico Mesoamericano. CCA-PNUD/GEF. RLA/95/G4, San José, Costa Rica.

García, R., Ortiz, L., 1991. Estudio Diagnóstico de las Áreas Protegidas de Costa Rica. San José, Costa Rica.

Gibson, C.C., Andersson, K. Ostrom, E., Shivakumar, S., 2005. The Samaritan's Dilemma: The Political Economy of Development Aid. Oxford University Press, New York, NY.

Gibson, C.C., Ostrom, E., Ahn, T.K., 2000. The concept of scale and the human dimensions of global change: a survey. Ecological Economics 32, 217-239.

Goertz, G., 2006. Structuring and theorizing concepts. In: Goertz, G. (Ed.), Social Science Concepts: A User's Guide. Princeton University Press, Princeton, NJ.

Gómez, L.D., Savage, J.M., 1983. Searchers on That Rich Coast: Costa Rican Field Biology, 1400-1980. University of Chicago Press, Chicago, IL.

Gunderson, L.H., Holling, C.S., 2002. Panarchy: Understanding Transformations in Human and Natural Systems. Island Press, Covelo, CA.

Gutierrez, N.L., Hilborn, R., Defeo, O., 2010. Leadership, social capital and incentives promote successful fisheries. Nature 470, 385-388.

Hayes, T., Persha, L., 2010. Nesting local forestry initiatives: revisiting community forest management in a REDD plus world. Forest Policy and Economics 12, $545-553$.

Heikkila, T., Schlager, E., Davis, M.W., 2011. The role of cross-scale institutional linkages in common pool resource management: assessing interstate river compacts. Policy Studies Journal 39, 121-145.

Janssen, M.A., Anderies, J.M., Ostrom, E., 2007. Robustness of social-ecological systems to spatial and temporal variability. Society \& Natural Resources 20 , 307-322.

Janzen, D.H., 2002. Tropical dry forest: area de conservacion guanacaste northwestern Costa Rica. In: Perrow, M.R., Davy, A.J. (Eds.), Handbook of Ecological Restoration: Restoration in Practice. Cambridge University Press, Cambridge, UK.

Matamoros, A., 2002. Historia de las Areas de Conservación. INBio, Santo Domingo, Heredia.

McCay, B.J., Acheson, J.M. (Eds.), 1987. The Question of the Commons: The Culture and Ecology of Communal Resources. University of Arizona, Tucson, AZ

McGinnis, M., Ostrom, E., 2008. Will lessons from small-scale social dilemmas scale up? In: Biel, A.E.D., Gärling, T., Gustaffson, M. (Eds.), New Issues and Paradigms in Research on Social Dilemmas. Springer, Berlin, pp. 189-211.

McKean, M.A., 1996. Common-property regimes as a solution to problems of scale and linkage. In: Hanna, S., Folke, C., Mäler, K.-G. (Eds.), Rights to Nature: Ecological, Economic, Cultural, and Political Principles of Institutions for the Environment. Island Press, Washington, DC, pp. 223-243.

Mena, Y.A., Artavia, G., 2004. Hacia la Administración Eficiente de las Áreas Protegidas: Políticas e Indicadores para su Monitoreo. Editorial INBio, Santo Domingo de Heredia, Costa Rica.

Nagendra, H., Tucker, C., Carlson, L., Southworth, J., Karmacharya, M., Karna, B., 2004. Monitoring parks through remote sensing: studies in Nepal and Honduras. Environmental Management 34, 748-760.

Olson, M., 1965. The Logic of Collective Action: Public Goods and the Theory of Groups. Harvard University Press, Cambridge, MA.

Ostrom, E., 1990. Governing the Commons: The Evolution of Institutions for Collective Action. Cambridge University Press, New York.

Ostrom, E., 1999. Coping with tragedies of the commons. Annual Review of Political Science 2, 493-535.

Ostrom, E., 2000. The danger of self-evident truths. PS: Political Science \& Politics $33,33-44$.

Ostrom, E., 2005. Understanding Institutional Diversity. Princeton University Press, Princeton, NJ.

Ostrom, E., 2007. A diagnostic approach for going beyond panaceas. Proceedings of the National Academy of Sciences 104, 15181-15187.

Ostrom, E., 2009. A general framework for analyzing sustainability of socialecological systems. Science 325, 419-422.

Ostrom, V., 1980. Artisanship and artifact. Public Administration Review 40, 309317.

Ostrom, V., Tiebout, C.M., Warren, R., 1961. The organization of government in metropolitan areas: a theoretical inquiry. American Political Science Review 55 831-842.

Pagdee, A., Kim, Y.S., Daugherty, P.J., 2006. What makes community forest management successful: a meta-study from community forests throughout the world. Society \& Natural Resources 19, 33-52.

Persha, L., Agrawal, A., Chhatre, A., 2011. Social and ecological synergy: local rulemaking, forest livelihoods, and biodiversity conservation. Science 331, $1606-1608$.

Pinkerton, E.W., 1992. Translating legal-rights into management practice: overcoming barriers to the exercise of comanagement. Human Organization 51 330-341.

Poteete, A.R., Janssen, M.A., Ostrom, E., 2010. Working Together: Collective Action, the Commons, and Multiple Methods in Practice. Princeton University Press, Princeton, NJ.

Ragin, C.C., 1987. The Comparative Method: Moving beyond Qualitative and Quantitative Strategies. University of California Press, Berkeley, CA. 
Ragin, C.C., 2000. Fuzzy-Set Social Science. University of Chicago Press, Chicago, IL. Ragin, C.C., 2008a. User's Guide to Fuzzy-Set/Qualitative comparative Analysis 2.0. Department of Sociology, University of Arizona, Tucson, AZ.

Ragin, C.C., 2008b. Redesigning Social Inquiry: Fuzzy Sets and Beyond. University of Chicago Press, Chicago, IL.

Ribot, J.C., Agrawal, A., Larson, A.M., 2006. Recentralizing while decentralizing: how national governments reappropriate forest resources. World Development 34, 1864-1886.

Rihoux, B., Ragin, C.C., 2009. Configurational Comparative Methods: Qualitative Comparative Analysis (QCA) and Related Techniques, Applied Social Research Methods Series. Sage, Thousand Oaks, CA.

Rockström, J., Steffen, W., Noone, K., Persson, A., Chapin, F.S., Lambin, E.F., Lenton, T.M., Scheffer, M., Folke, C., Schellnhuber, H.J., Nykvist, B., de Wit, C.A., Hughes, T., van der Leeuw, S., Rodhe, H., Sorlin, S., Snyder, P.K., Costanza, R., Svedin, U., Falkenmark, M., Karlberg, L., Corell, R.W., Fabry, V.J., Hansen, J., Walker, B., Liverman, D., Richardson, K., Crutzen, P., Foley, J.A., 2009. A safe operating space for humanity. Nature $461,472-475$.

Rudd, M.A., Tupper, M.H., Folmer, H., Van Kooten, G.C., 2003. Policy analysis for tropical marine reserves: challenges and directions. Fish and Fisheries 4, 65-85.

Rudel, T.K., 2005. Tropical Forests. Regional Paths of Destruction and Regeneration in the Late Twentieth Century. Columbia University Press, New York.

Rudel, T.K., 2008. Meta-analyses of case studies: a method for studying regional and global environmental change. Global Environmental Change 18, $18-25$.

Sanchez-Azofeifa, G.A., Kalacska, M., Quesada, M., Calvo-Alvarado, J.C., Nassar, J.M., Rodriguez, J.P., 2005. Need for integrated research for a sustainable future in tropical dry forests. Conservation Biology 19, 285-286.

Schlager, E., 2002. Rationality, cooperation, and common pool resources. American Behavioral Scientist 45, 801-819.

Schlager, E., 2004. Common-pool resource theory. In: Durant, R.F., Fiorino, D.J., O'Leary, R. (Eds.), Environmental Governance Reconsidered: Challenges, Choices, and Opportunities. MIT Press, Cambridge, MA.

Schneider, C.Q., Wagemann, C., 2010. Standards of good practice in qualitative comparative analysis (QCA) and fuzzy-sets. Comparative Sociology 9, 397-418.

Shepsle, K.A., 1989. Studying institutions: some lessons from the rational choice approach. Journal of Theoretical Politics 1, 131-147.
SINAC, 2013. Location of SINAC's conservation areas. Map. https://www.sinac.go.cr/ Paginas/Inicio.aspx (accessed 08.01.13).

SINAC-MINAE, 2002. Agenda para las Áreas Silvestres Protegidas Administradas por el SINAC, San José, Costa Rica.

SINAC-MINAE, 2003. Informe Nacional sobre el Sistema de Áreas Silvestres Protegidas, San José, Costa Rica.

SINAC-MINAE, 2006. El Sistema de Áreas Silvestres Protegidas de Costa Rica. Informe Nacional, II Congreso Mesoamericano de Áreas Protegidas. Ministerio de Ambiente y Energía, Panamá.

Steinberg, P.F., 2001. Environmental Leadership in Developing Countries: Transnational Relations and Biodiversity Policy in Costa Rica and Bolivia. MIT Press, Cambridge, MA.

Trench, T., 2008. From "orphans of the state" to the comunidad conservacionista institucional: the case of the Lacandon community, Chiapas. Identities-Global Studies in Culture and Power 15, 607-634.

Ugalde, A., 1989. Análisis de Políticas de Manejo de Áreas Silvestres de Costa Rica, Final Report to MINENEM and Conservation International, San José, Costa Rica.

Wade, R., 1994. Village Republics: Economic Conditions for Collective Action in South India. ICS Press, San Francisco, CA.

Wilson, J.A., 2006. Matching social and ecological systems in complex ocean fisheries. Ecology and Society 11.

Young, O.R., 1996. Rights, rules, and resources in international society. In: Hanna, S., Folke, C., Mäler, K.-G. (Eds.), Rights to Nature: Ecological, Economic, Cultural, and Political Principles of Institutions for the Environment. Island Press, Washington, DC.

Young, O.R., 2002a. The Institutional Dimensions of Environmental Change: Fit, Interplay, and Scale. MIT Press, Cambridge, MA.

Young, O.R., 2002b. Usable knowledge: design principles and institutional diagnostics. In: Young, O.R. (Ed.), The Institutional Dimensions of Environmental Change: Fit, Interplay, and Scale. MIT Press, Cambridge, MA.

Young, O.R., King, L.A., Schroeder, H., 2008a. Building regimes for socioecological systems: institutional diagnostics. In: Young, O.R., King, L.A., Schroeder, H. (Eds.), Institutions and Environmental Change: Principal Findings, Applications, and Research Frontiers. MIT Press, Cambridge, MA

Young, O.R., King, L.A., Schroeder, H., 2008b. Institutions and Environmental Change: Principal Findings, Applications, and Research Frontiers. MIT Press, Cambridge, MA. 